\title{
Hypothermia in bleeding trauma: a friend or a foe? Tareq Kheirbek ${ }^{1,2}$, Ashley R Kochanek ${ }^{1}$ and Hasan B Alam*1
}

Address: ${ }^{1}$ Department of Surgery, Division of Trauma, Emergency Surgery and Surgical Critical Care, Massachusetts General Hospital/Harvard Medical School, Boston, MA, USA and 2Department of Surgery, Washington Hospital Center, Washington, DC, USA

Email: Tareq Kheirbek - hbalam@partners.org; Ashley R Kochanek - akochanek@partners.org; Hasan B Alam* - hbalam@partners.org

* Corresponding author

Published: 23 December 2009

Scandinavian Journal of Trauma, Resuscitation and Emergency Medicine 2009, 17:65 doi:10.1 186/1757-7241-17-65

This article is available from: http://www.sjtrem.com/content//7/1/65

(c) 2009 Kheirbek et al; licensee BioMed Central Ltd.

This is an Open Access article distributed under the terms of the Creative Commons Attribution License (http://creativecommons.org/licenses/by/2.0), which permits unrestricted use, distribution, and reproduction in any medium, provided the original work is properly cited.
Received: 16 July 2009

Accepted: 23 December 2009

\begin{abstract}
The induction of hypothermia for cellular protection is well established in several clinical settings. Its role in trauma patients, however, is controversial. This review discusses the benefits and complications of induced hypothermia--emphasizing the current state of knowledge and potential applications in bleeding patients. Extensive pre-clinical data suggest that in advanced stages of shock, rapid cooling can protect cells during ischemia and reperfusion, decrease organ damage, and improve survival. Yet hypothermia is a double edged sword; unless carefully managed, its induction can be associated with a number of complications. Appropriate patient selection requires a thorough understanding of the pre-clinical literature. Clinicians must also appreciate the enormous influence that temperature modulation exerts on various cellular mechanisms. This manuscript aims to provide a balanced view of the published literature on this topic. While many of the advantageous molecular and physiological effects of induced hypothermia have been outlined in animal models, rigorous clinical investigations are needed to translate these promising findings into clinical practice.
\end{abstract}

\section{Introduction}

Uncontrolled hemorrhage is characterized by progression from regional hypoperfusion to a state of total body ischemic insult and ends in irreversible tissue damage and death. While tissue hypoxia and excessive bleeding are undisputed harbingers of death[1], hypothermia's role in trauma is complex and context dependent. A spontaneous decrease in core body temperature following injuries correlates with poor prognosis. However, numerous studies have shown that induction of hypothermia is a potent strategy for preserving tissues and improving survival following ischemia-reperfusion events $[2,3]$. These studies beg the question- is hypothermia friend or foe in trauma?

There is no strictly accepted nomenclature to define the depth of clinically induced therapeutic hypothermia.
Since the physiologic response of tissues to hypothermia differs according to its degree, it is important to stratify the current literature correspondingly. For the purposes of this review the depth of therapeutic hypothermia will be classified into: mild $\left(33-36^{\circ} \mathrm{C}\right)$, moderate $\left(28-32^{\circ} \mathrm{C}\right)$, deep $\left(16-27^{\circ} \mathrm{C}\right)$, profound $\left(6-15^{\circ} \mathrm{C}\right)$, and ultra-profound $\left(<5^{\circ} \mathrm{C}\right)$ hypothermia. In addition, the effects of hypothermia on tissues are also modulated by numerous other variables such as timing (before or after the ischemic insult), etiology (spontaneous or induced), presence or absence of associated injuries, rate of induction and reversal, duration of hypothermia, and therapeutic approach (mild to moderate hypothermia during shock vs. profound hypothermia during arrest), to name a few. It is clearly beyond the scope of this review to categorize and analyze the literature according to all of these variables. The goal of this 
paper, therefore, is to provide a broad over view of the topic for the general readership, while citing the specific references in the bibliography for those who might be interested in obtaining more detailed information.

\section{Background}

Trauma is the major cause of death in individuals aged 1 to 34 years and is the fifth leading cause of mortality in the United States--with uncontrolled hemorrhage representing the major cause of preventable deaths [4]. In spite of progress made in all major disease categories in the United States and Europe, injuries remain at the same absolute levels, and represent an increasing relative share as a major cause of mortality, especially in males [5]. The estimated cost of injuries in the U.S. was $\$ 406$ billion for the year 2000 [6], which is incontrovertibly compounded by the emotional and financial burden on the patients and their families.

Traditionally, the first line approach to the bleeding trauma patients was based on replacement of acute blood losses in an attempt to maintain tissue perfusion and sustain aerobic metabolism. This therapy alone is inadequate, impractical and even harmful in many circumstances. Not only are appropriate blood products often unavailable but aggressive fluid resuscitation can actually exacerbate bleeding and worsen cellular injury [79]. The definitive therapy for bleeding patients continues to be surgical control of the bleeding site [10], yet most deaths from bleeding occur prior to arrival in a hospital [11], or soon after admission [12]. Furthermore, critical warm ischemia time is under five minutes for the brain $[13,14]$ and around twenty minutes for the heart [15]. Thus, even if source of hemorrhage is controlled and spontaneous circulation restored, significant morbidity and mortality can result from the ischemia and reperfusion insults.

Dr R. Adams Cowley recognized this need for urgent care following trauma and popularized the concept of the "Golden Hour" in trauma care. This delineates the time during which proper management can save life but beyond which irreversible damage occurs. This principle was later adopted by the American College of Surgeons in Advanced Trauma Life Support (ATLS) training [16]. Today, the need to lengthen the Golden Hour, especially on the battlefield, remains pressing and has inspired new urgency in the development and implementation of novel therapies to protect the vital organs from hypoxicischemic insult.

\section{Pathophysiology of Hemorrhagic Shock}

To understand the potential applications of hypothermia in bleeding trauma patients one must appreciate the phys- iologic and molecular consequences of hypovolemic hypoxic shock.

The biological response to hemorrhage is a combination of cardiovascular compensation and competing activation of cellular survival and death pathways within vital organs, especially the heart, lung, liver, kidney and brain. Physiologically, increased heart rate and catecholamines release increases the peripheral vascular resistance in order to maintain cardiac output and meet metabolic demands. Hypovolumia activates the renin-angiotensin system to retain water and sodium. However, when uncontrolled blood loss continues these mechanisms eventually fail. Tissue hypoperfusion ensues and the patient enters a state of shock.

At a cellular level, aerobic metabolism of oxidative fuels provides the energy to carry out the necessary functions. Metabolic homeostasis requires steady oxygen delivery to maintain oxidative phosphorylation in the mitochondria and generate adenosine triphosphate (ATP). Since little oxygen is stored in tissues, aerobic ATP synthesis is quickly impaired by a mismatch between oxygen supply and demand [17]. Significant blood loss decreases oxygen delivery $\left(\mathrm{DO}_{2}\right)$ while oxygen uptake $\left(\mathrm{VO}_{2}\right)$ remains fairly constant. Oxygen extraction increases to compensate for this mismatch but soon reaches its physiological limits. Aerobic $\mathrm{VO}_{2}$ can no longer be maintained and tissues resort to anaerobic metabolism $[18,19]$. In this inefficient, hypoxic and hypovolemic state, ATP utilization exceeds ATP production. Rapid depletion of intracellular ATP leads to cellular dysfunction and organ decompensation [20-23].

Notably, cells sense low oxygen tension well before ATP pools are depleted [24]. For example, hypoxic stimulus leads to increased stability and expression of hypoxiainduced factor 1 (HIF-1) in these cells. HIF-1 is a regulator for multiple molecules and pathways, such as erthropoiesis, angiogenesis, vasodilatation, and anaerobic metabolism [25]. It also activates inflammatory pathways including stress-activated protein c-jun kinase (JNK) [26] and induced nitric oxide synthase (iNOS) [27]. Nitric oxide (NO), in turn, activates nuclear factor kappa B (NF$\mathrm{kB}$ ), increases levels of downstream inflammatory cytokines [28] and contributes to lung and liver injury. Thus, tissues are primed for inflammatory and immunemediated injury during this early hypoperfused, hypoxic state.

As hemorrhage progresses, hypoperfusion decouples the redox state in affected cells and initiates several unfavorable events [29]. Energy deficits secondary to shock significantly disrupt transmembrane ion transport. Intracellular $\mathrm{Ca}^{+2}$ increases to deleterious levels as ATP dependent ion 
pumps fail to pump $\mathrm{Ca}^{2+}$ out. An increased intracellular and intra-mitochondrial $\mathrm{Ca}^{2+}$ concentration reduces the efficiency of oxidative phosphorylation and activates cell death pathways $[30,31]$. Moreover, this $\mathrm{Ca}^{2+}$ excess persists and even worsens when circulation is restored.

Ineffective oxidative metabolism also leads to an accumulation of nicotinamide adenine dinucleotide (NADH), which alters pyruvate metabolism and accelerates lactate production [20]. This development correlates with an increase in morbidity and mortality following shock [32]. Likewise, supplementing resuscitation fluids with ATP$\mathrm{MgCl}_{2}$ to treat this energy deficient and acidosis have been shown to restore membrane integrity [33] and mitochondrial function $[34,35]$, attenuate lactate levels, prevent reperfusion injury to the kidney and the liver [36-41], and improve survival [42].

\section{Reperfusion Injury}

Treating hemorrhage is more complicated than simply stopping the bleeding, replacing volume, and restoring energy losses. Aggressive fluid resuscitation is associated with cardiac and pulmonary consequences as well as coagulation disturbances, inflammation, and immunologic dysfunction [43]. The inflammation/cell damage that starts early in hemorrhage is often exacerbated by restoring the blood flow [44]. Reperfusion creates a rapid influx of oxygen and substrates for aerobic metabolic that overwhelms injured mitochondria and promotes the generation of reactive oxygen species. Restoring flow also activates neutrophils and enables them to invade affected tissues $[45,46]$. Invading neutrophils release inflammatory cytokines including interleukin (IL)-6, granulocyte colony-stimulating factor (G-CSF), and tumor necrosis factor alpha (TNF-alpha) $[47,48]$. These cytokines play an important role in perpetuating the vicious cycle of inflammation. Activation of signal transducers and activators of transcription (STAT) proteins perpetuates the inflammatory response and neutrophil invasion [49]. Activated cytokines also promote the expression of mediators in apoptotic pathways [50] that can contribute to organ dysfunction $[51,52]$.

The sum of hemorrhage, ischemic injury and reperfusion insult manifests locally as increased cell death and systemically as organ failure. Apoptosis, necrosis, and inflammation are evident in different organs within hours after shock and resuscitation [53-56]. These early inflammatory and apoptotic changes not only indicate ischemic injury but also are precursors of post-traumatic immunosuppresion [57], acute respiratory distress syndrome (ARDS), and multiple organ failure syndrome (MODS) [58].

\section{Hypothermia and Hemorrhage: A History}

Humans have long admired the protective properties of hypothermia, and a brief historical description might be helpful before critically analyzing the contemporary data. Historical evidence suggests that ancient cultures in Egypt and Peru performed mummification in cold chambers in the hopes of restoring their rulers to life. Inspired by observations of hibernating animals and individuals surviving extremely cold conditions, their reasoning may possess some validity, even if their methods were less than scientific.

The concept of hypothermic therapy as a remedy for febrile illness and pain relief originated in ancient medicine [59]. However, the first deliberate induction of therapeutic hypothermia did not take place until the $20^{\text {th }}$ century. In 1938 Temple Fay and Lawrence Smith attempted deep cooling treatments to decelerate tumor growth in cancer patients without success [60]. Over the next two decades the scientific community developed a better understanding of the physiologic and therapeutic properties of temperature modulation [61,62]. During this period, confidence in the benefits of hypothermia--its ability to decrease metabolic activity, reduce oxygen demands, and preserve tissues during ischemia--slowly expanded, along with greater insights into therapeutic cooling's risks [63].

Shortly thereafter, medical experiences in World War II and the Korean War heightened the medical and military community's awareness of hemorrhagic shock and the need for superior treatment strategies. This prompted some physicians to reevaluate the feasibility of inducing moderate $\left(30^{\circ} \mathrm{C}\right)$ hypothermia as a treatment for severe blood loss in animals, and even try it on some patients in the battlefield [64]. These early experiments suffered from serious flaws in study designs, and not surprisingly produced conflicting results [65].

Thus, while protective hypothermia became well-established in cardiac, vascular, and neurosurgery $[66,67]$ and is now considered beneficial in neonatal hypoxicischemic encephalopathy and out-of-hospital cardiac arrest $[68,69]$, its role in traumatic injury has remained controversial.

Indeed, bleeding trauma patients differ from the elective surgical patients. In elective surgery patients, hypothermia is induced prior to ischemia under controlled settings. Even in the context of an out of hospital cardiac arrest, hypothermia is induced in patients with no additional injuries or significant blood loss. Contrastingly, trauma patients have well established tissue ischemic before they can be become candidates for induction of hypothermia. In addition, they are hemodynamically unstable, coagulo- 
pathic, and suffering from multiple wounds. Clearly, the risks and benefit of therapeutic hypothermia must be carefully weighed in these challenging patients.

Fortunately, recent studies employing more rigorous models have validated hypothermia's ability to improve survival, cellular viability, and cognitive function during hemorrhagic shock and prolonged periods of ischemia [70-74]. These findings have piqued renewed interest in therapeutic applications for trauma patients.

\section{Induced Therapeutic Hypothermia and Spontaneous Hypothermia: Friend and Foe}

Induced hypothermia and hypothermia secondary to hemorrhagic shock are two very different physiological states that yield correspondingly disparate outcomes $[75,76]$.

\section{Spontaneous Hypothermia}

Spontaneous hypothermia after major trauma is associated with greater transfusion and fluid requirements and worse outcomes $[75,77,78]$. Many severely injured patients arrive in the emergency department (ED) hypothermic and the incidence is increased by maneuvers performed in the ED such as clothing removal, cold fluid administration, opening body cavities, and the use of anesthetic agents [79]. Spontaneous hypothermia indicates depleted energy stores, disrupted cellular homeostasis $[80,81]$ and therefore correlates with more severe injuries. Indeed, spontaneous hypothermia along with coagulopathy and acidosis are widely recognized as a "lethal triad" that correlates with poor outcome in trauma patients. Hypothermia (body temperature $<35^{\circ} \mathrm{C}$ ) upon admission independently associated with increased mortality in two retrospective studies that controlled for injury severity [75,81]. Yet association does not necessarily imply causality, and deliberately induced hypothermia can be life saving.

At a cellular level, ATP depletion plays a major role in the pathophysiology of spontaneous hypothermia. Since heat production in the body comes from hydrolysis of ATP to adenosine diphosphate (ADP) [82], anaerobic metabolism due to shock usually involves decreased ATP synthesis and eventually hypothermia. Seekamp et al. compared ATP levels in trauma patients (normothermic and hypothermic) to the levels in patients undergoing elective surgery (including hypothermia for coronary artery bypass operations) [83], and demonstrated that ATP levels were the lowest in trauma patients who presented with core temperature $<34$ degrees. Contrastingly, in the hypothermic elective surgery group, patients experienced only a small and transient decrease in ATP levels, which returned to baseline within 24 hours. Changes in ATP also correlated inversely with lactate levels - corroborating hypo- thermia as a sequela of energy depletion secondary to hypoxia and anaerobic metabolism. It should also be pointed out that thermoregulatory mechanisms stimulate strong sympathetic response and shivering to counteract decreasing core body temperature [84]. The resultant increase in muscular metabolic demand provokes a decompensated thermostasis and a worsened metabolic acidosis [85].

Clinically, accidental hypothermia is also associated with myocardial dysfunction, which manifest as decreased cardiac output, bradycardia, and pathognomonic J wave on the electrocardiograph. Arterial and ventricular fibrillation are subsequently seen with worsening hypothermia and central respiratory depression [86]. In a trauma/hemorrhage model, animals that became spontaneously hypothermic and were maintained at hypothermic body temperature $\left(32^{\circ} \mathrm{C}\right)$ during resuscitation demonstrated depressed cardiac function whereas animals that were restored to normothermia during resuscitation demonstrated increased cardiac output comparable to sham animals [87].

Hemodynamically, hemorrhage increases the viscosity of blood and decreases platelet and coagulation enzymes activity, worsening trauma-induced coagulopathy $[88,89]$. When shock is complicated by hypothermia, these deleterious changes become additive and a worse prognosis ensues [90]. Figure 1 represents a simple design of heat generation process in aerobic environment. Figure 2 illustrates the cellular changes associated with hemorrhagic shock and the development of spontaneous hypothermia.

\section{Therapeutic Hypothermia}

In contrast, induction of hypothermia in a controlled manner can protect tissues from ischemic injury $[91,92]$. As mentioned before, it requires appropriate sedation and neuromuscular blockade to minimize the deleterious effects of intense shivering that occur between $34-36^{\circ} \mathrm{C}$. In this therapeutic context, controlled decreases in core body temperature are associated with decreased metabolic and oxygen demands in tissues [3], reduced activation of cell death pathways, and blunted inflammatory and immune response.

Induced hypothermia generates a state of metabolic depression that preserves cellular energy when oxygen and substrates are in limited supply. Hypothermia attenuates the activity of $\mathrm{Na}+/ \mathrm{K}+$ ATPase pump that is responsible for up to $40 \%$ of ATP utilization in different tissues [93]. Cellular ATP levels decrease during shock according to the duration of ischemia. If blood flow is restored within the safe period of ischemia, ATP is regenerated [94], cellular function remains viable, and survival 


\section{Normal Cell Functions}

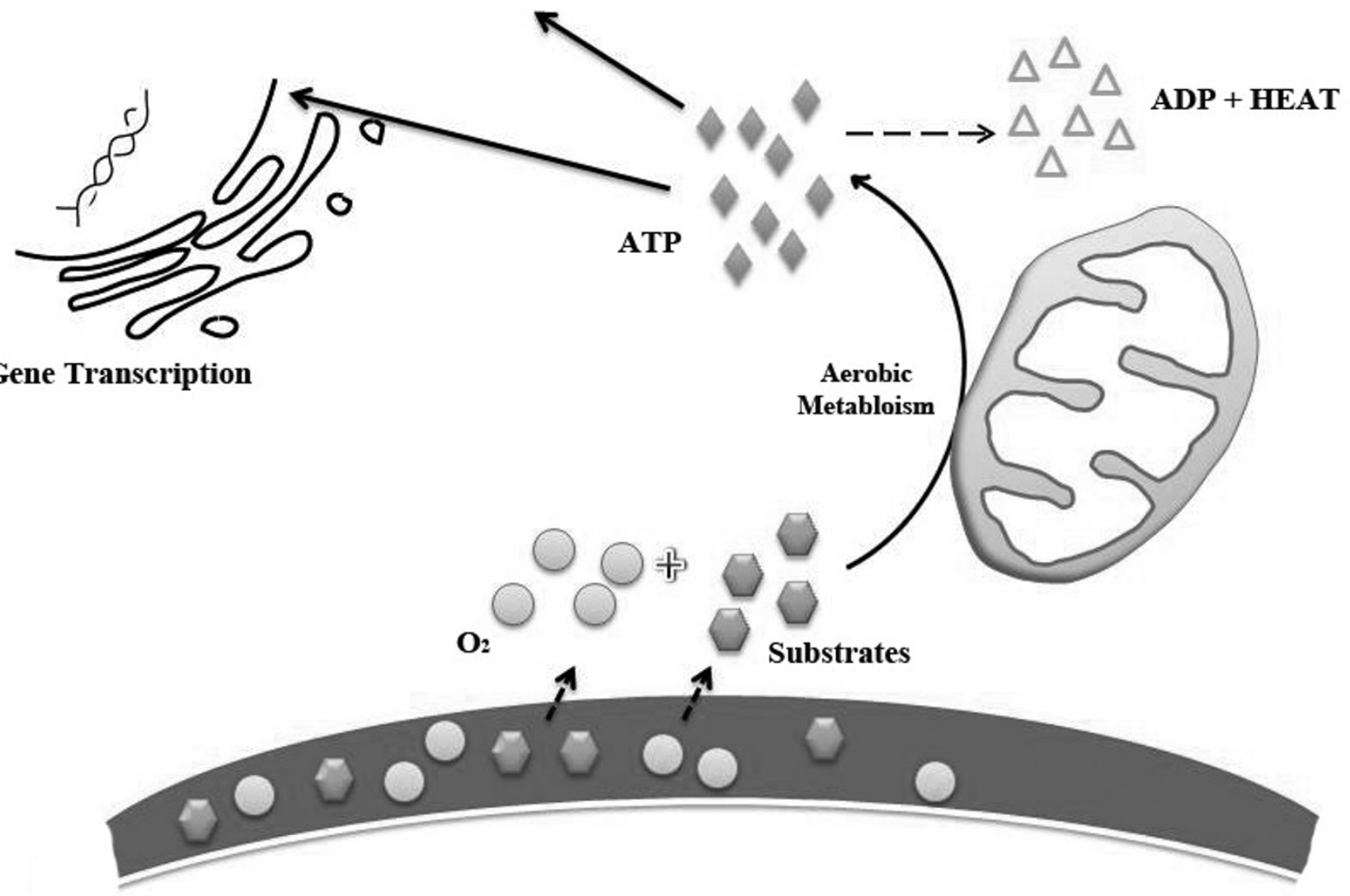

Figure I

Aerobic metabolism in the cell guarantees adequate ATP for normal physiologic function and heat production (thermoregulation). ATP = Adenosine Tri-Phosphate. ADP = Adenosine Di-Phosphate.

improves. Hypothermia can prolong this safe ischemic window. Animal studies from transplant, trauma, and brain injury literature have successfully demonstrated preservation of ATP levels in organs stored or treated with hypothermia $[95,96]$. Meyer et al. studied the effect of moderate, induced hypothermia after hemorrhagic shock in dogs and found decreased metabolic needs, maintained myocardial contractility and lower oxygen consumption and extraction compared to normothermic animals [97]. Ibayashi et al. showed that lowering brain temperature reduced global and regional cerebral blood flow; the concentration of brain ATP was significantly higher in hypothermic rats compared to normothermic group after 60 minutes of ischemia [98]. It is hypothesized that selective brain hypothermia decreases the basal metabolic rate in the brain, slows glucose and phsophocreatine breakdown, reduces lactate and inorganic phosphate formation, and thereby limits cellular damage during ischemia and reperfusion [99].
Induced hypothermia also alters cell survival and stress pathways that maintain tissue viability. In a rabbit model of ischemia-reperfusion, hypothermic animals exhibited decreased expression of pro-apoptotic proteins, transformation-related protein ( $p 53)$ and bak, and an increased expression of anti-apoptotic Bcl-2 homologue Bcl- $x$ [100]. In rodent model of hemorrhagic shock, profound hypothermia preserved Akt in cardiac myocytes, activated prosurvival proteins including $\mathrm{Bcl}-2$ and beta catenin and suppressed Bad and caspase-3 activation [101]. Hypothermia also suppresses apoptosis by down regulating expression of TNF receptor (TNFR1) [102] and its associated pro-death ligand, apoptosis stimulating fragment (Fas) protein. Moderate hypothermia has been shown to suppress Fas-mediated apoptosis in stored cultured hepatocytes, along with suppression of cytochrome-c release from mitochondria and downstream activation of caspase-7 and caspase-9 [103]. Moderate hypothermia abolished hepatic STAT activity in an intestinal ischemia- 


\section{Spontaneous Hypothermia}

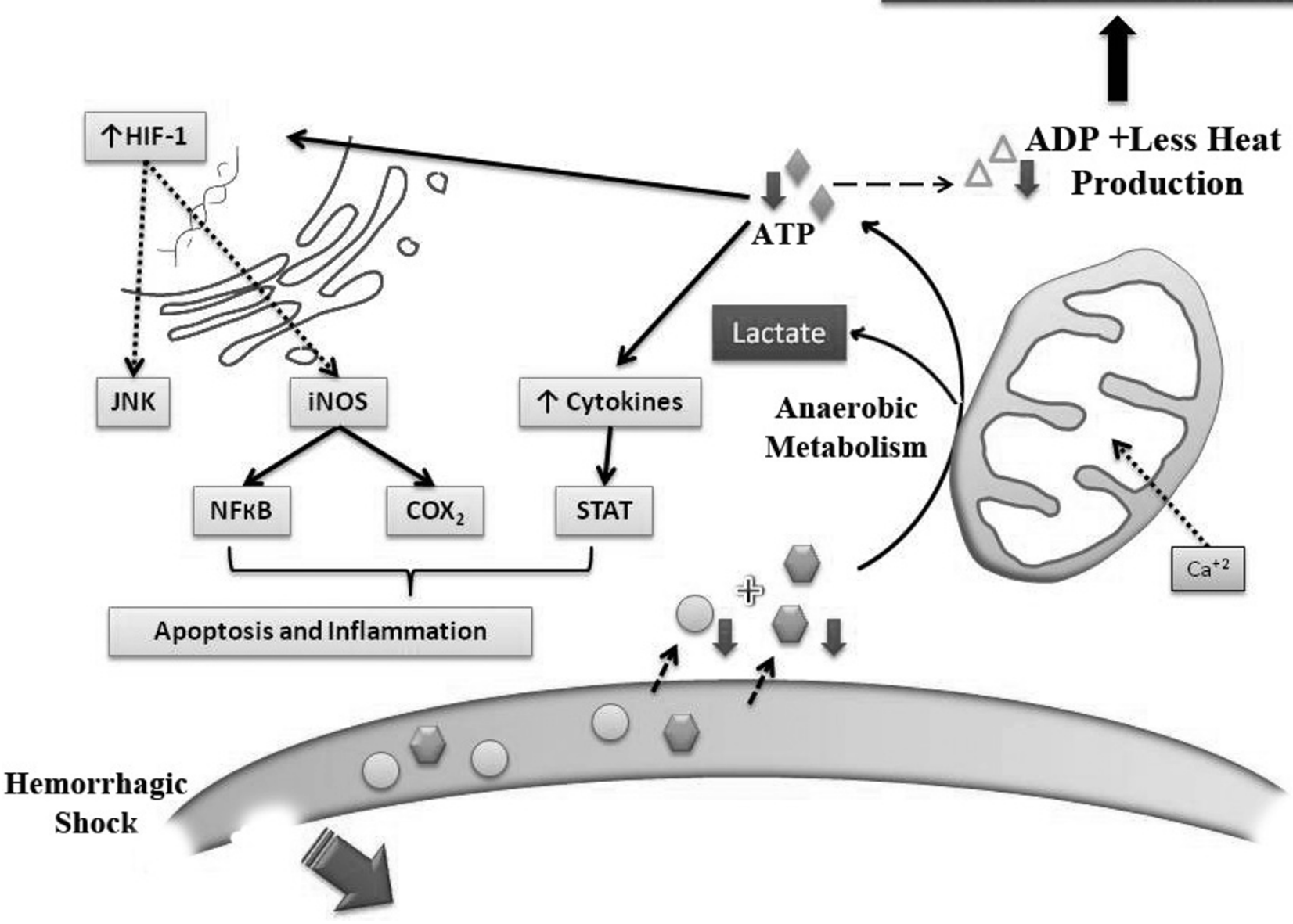

Figure 2

Hemorrhage reduces availability of oxygen and substrates and stimulates a switch to anaerobic metabolism leading to decreased ATP synthesis and subsequent heat production. This cellular hypoxia also stabilizes HIF-I, which activates several inflammatory and apoptotic pathways leading to increased cell injury and death. ATP = Adenosine TriPhosphate. ADP = Adenosine Di-Phosphate. HIF-I = Hypoxia-Induced Factor-I. iNOS- induced Nitric Oxide Synthase. NO = Nitric Oxide. $\mathrm{PG}=$ Prostaglandin. NF-kB $=$ Nuclear Factor- kappa B. COX-2 = cyclo-oxygenase-2. IL $=$ Interleukins. TNF $\alpha=$ Tumor Necrosis Factor alpha. G-CSF = Granulocytes Colony Stimulating Factor. STAT = Signal Transducers and Activators of Transcription.

reperfusion rat model, suggesting a hepatoprotective role for induced hypothermia as well [104].

Moreover, hypothermia significantly attenuates the inflammatory and immune response associated with hemorrhagic shock, ischemia, and surgery. In a hepatic ischemic-reperfusion model, topical deep hypothermia protected the liver from necrosis, decreased neutrophil infiltration, reduced serum levels of TNF- $\alpha$, and reduced the associated lung injury [105]. In addition to modulating local immune cell invasion, induced hypothermia can decrease the release of pro-inflammatory cytokines believed to influence distant organ damage, systemic shock, and development of immune mediated patholo- gies such as ARDS and sepsis [106]. For example, in cardiac surgery, moderate hypothermia is associated with decreased TNF- $\alpha$, IL-1, and IL-6, reduced complement activation and C-reactive protein (CRP) concentration, and an increase in anti-inflammatory IL-10 [107-110]. Figure 3 demonstrates some of the molecular changes associated with induced hypothermia

\section{Side Effects of Clinically Induced Hypothermia}

Even though many of physiological and molecular changes in response to hypothermia are advantageous, depressing core body temperature is not without potential complications. In order to use hypothermia as an ally instead of an adversary in trauma, great care must be exer- 


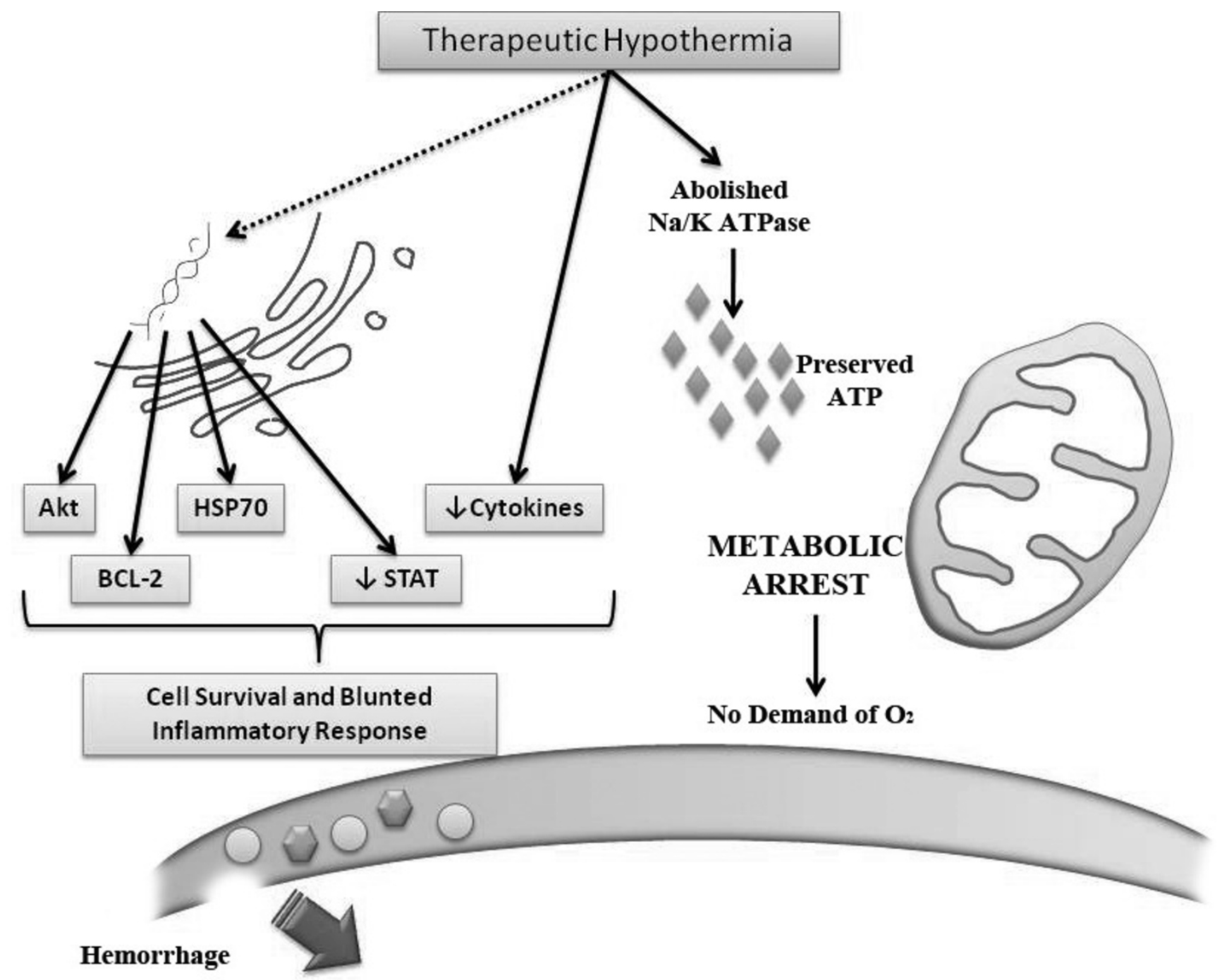

Figure 3

The molecular changes associated with induced therapeutic hypothermia. Minimal metabolic activity due to inactivation of $\mathrm{Na}^{+} / \mathrm{K}^{+}$ATPase pump conserves ATP in the cell and abolishes the need for oxygen and substrates during the circulatory arrest. Induced hypothermia also affects several molecular pathways altering the expression of many intermediates and leads to decreased inflammation, decreased neutrophils migration and decrease apoptosis. Production of ROS is blunted as well. TNFR $=$ Tumor Necrosis Factor Receptor. Cyt $-\mathrm{C}=$ Cytochrome . ROS $=$ Reactive Oxygen Species. STAT $=$ Signal Transducers and Activators of Transcription. HSP $70=$ Heat Shock Protein. JNK = stress-activated protein c-jun Kinase.

cised to optimize the therapeutic benefits while avoiding the deleterious consequences of unregulated cooling.

\section{A. Dysrhythmias}

Induction of hypothermia causes an initial increase in heart rate, cardiac output and systemic vascular resistance followed by a decrease in heart rate and cardiac output once temperatures are less than $30^{\circ} \mathrm{C}$. Typically, heart rate slows down markedly below $28^{\circ} \mathrm{C}$ and eventually leads to asystole by the time deep hypothermia is achieved. Since induced hypothermia also reduces metabolic demand, this negative chronotropic effects should not significantly disrupt the energy supply and demand equilibrium. Moderate hypothermia has also been associated with elevated risk of cardiac dysrhythmias, J waves, first degree heart block, and prolonged QT [111]. A clinical trial of moderate hypothermia in pediatric traumatic brain injury patients observed increased arrhythmias (which were manageable with standard interventions) in their hypothermia group and a trial of moderate hypothermia for neonatal encephalopathy reported more frequent bradycardia[112,113]. The generalizability of these findings to adult trauma patients is uncertain. Correspondingly, continuous monitoring of cardiac and metabolic parameters 
is essential, but potential for complications is small for mild-moderate hypothermia.

\section{B. Coagulopathy}

Hypothermia decreases the enzymatic activity of clotting factors and reduces the number and function of platelets [114]. This effect is dependent upon the depth of hypothermia and becomes clinically measurable when core temperature drops below $33^{\circ} \mathrm{C}$. Thus, it is not surprising that the incidence of coagulopathy is inconsistent in preclinical and human studies of mild-moderate hypothermia. Mild hypothermia has been associated with increased PT and PTT in a porcine model of hemorrhagic shock [89] but it had no significant coagulopathic effects in other animal studies $[71,115]$. In pediatric patients, deep hypothermic circulatory arrest during cardiac surgery has been associated with increased bleeding and transfusion requirements [116]. In adults, a study of trauma patients reported impaired platelet function but normal fibrinolysis [117]. And, a meta-analysis of clinical trials of mild therapeutic hypothermia for traumatic head injury determined that PTT was slightly increased (0.02 seconds) in the hypothermia group [118].

Consequently it is important to closely monitor coagulation parameters. However, coagulopathy does not uniformly occur until the temperature drops below $33^{\circ} \mathrm{C}$. Also, in the setting of mild to moderate hypothermia the changes in laboratory measures of coagulation do not necessarily lead to worse outcomes.

Deep and profound hypothermia indeed cause reversible coagulopathy which corrects rapidly once the temperature is brought back to normal. The consequences of this coagulopathy must be measured against the potential advantages. Clearly excessive blood loss in a trauma patient is not desirable. But short durations of coagulopathy may be tolerable when controlling life threatening hemorrhage. For these select patients, transient coagulopathy may be an acceptable tradeoff to preserve key organs during periods of critical ischemia. Interestingly, as the tissue oxygen demands are minimal during profound hypothermia, coagulopathy and additional blood loss are very well tolerated in animal models.

\section{Infections}

Hypothermia blunts the immune response, and decreases cytokine production and neutrophil migration. While this immunological attenuation protects tissues from reperfusion injury and inflammatory damage, it may also increase the risk of infection. In a randomized controlled trial of elective surgery patients, normothermia reduced surgical wound infection rates when compared to perioperative mild hypothermia [119]. Studies have also reported increased pneumonia in patients receiving thera- peutic hypothermia for traumatic brain injury $[120,121]$. These patients are clearly at a high risk for developing pneumonia due to need for prolonged mechanical ventilation. At the same time, several studies have shown no increase in the infection rates with the use of hypothermia $[112,122]$.

As with coagulopathy, risks of infections must be balanced against the life saving potential of this therapeutic intervention. The duration and depth of hypothermia are critical variables that influence the infection rates--a short duration of profound hypothermia is not the same as prolonged periods of mild-moderate hypothermia. For example, no infectious complications were noted during a six week observation period in our animal models in which lethal vascular injuries were repaired during a short period (60 minutes) of profound $\left(10^{\circ} \mathrm{C}\right)$ hypothermia [123]. However, it is reasonable to start perioperative antibiotic coverage prior to instrumentation and induction of hypothermia, and ventilator-associated pneumonia (VAP) precautions should also be routinely maintained in intubated subjects.

\section{Drug metabolism}

Hypothermia decreases the systemic clearance of cytochrome P450 metabolized drugs between approximately $7 \%$ and $22 \%$ per degree Celsius below $37^{\circ} \mathrm{C}$. The therapeutic index of drugs is narrowed during hypothermia and the pharmacokinetics of many drugs may be altered [124]. Treating physicians should be aware of these changes and adjust pharmacotherapy accordingly.

Table 1 summarizes the major physiologic and metabolic changes that need to be considered in hemorrhagic shock complicated by hypothermia, and in the induction of mild therapeutic hypothermia and emergency preservation and resuscitation (EPR).

\section{Novel Strategies: Beyond the Golden Hour}

Current management strategies are inadequate in the face of advanced hemorrhage. There is a clear need to develop a novel approach that can extend the Golden Hour, facilitate surgical repair, modulate metabolic demands, attenuate immune and inflammatory responses, and preserve vital tissues. Pre-clinical data strongly suggests that induced hypothermia has significant potential as a therapeutic modality for Emergency Preservation and Resuscitation (EPR) in severe trauma.

\section{Therapeutic Hypothermia in Bleeding Trauma Patients: Preclinical Potential}

Most studies demonstrating beneficial effects of therapeutic hypothermia have focused on clinical scenarios such as cerebral ischemia, cardiac arrest, and transplantation. Although no human studies have been performed to eval- 
Table I: Comparison of physiologic and metabolic changes associated with hemorrhagic shock with those changes specific to hemorrhagic shock combined spontaneous hypothermia or induced therapeutic hypothermia.

\begin{tabular}{|c|c|c|c|c|}
\hline & Hemorrhagic Shock & $\begin{array}{l}\text { Hemorrhagic Shock } \\
\text { Complicated by } \\
\text { Spontaneous Hypothermia }\end{array}$ & $\begin{array}{l}\text { Therapeutic Mild } \\
\text { Hypothermia in } \\
\text { Hemorrhagic Shock }\end{array}$ & $\begin{array}{l}\text { Emergency Preservation } \\
\text { Resuscitation in } \\
\text { Hemorrhagic Shock }\end{array}$ \\
\hline Cardiac & $\begin{array}{l}\text { Hypotension, tachycardia } \\
\text { Hypovolemic shock }\end{array}$ & $\begin{array}{l}\text { Cardiac depression } \\
\text { Bradycardia } \\
\text { Arrhythmias with worsening } \\
\text { hypothermia - J waves }\end{array}$ & $\begin{array}{l}\text { Bradycardia } \\
\text { Decreased risk of cardiac } \\
\text { arrest }\end{array}$ & $\begin{array}{l}\text { Induced cardiac arrest on } \\
\mathrm{CPB} \text { with low flow state }\end{array}$ \\
\hline Respiratory & Variable & Central respiratory depression & $\begin{array}{l}\text { Variable } \\
\text { Carefully monitored }\end{array}$ & $\begin{array}{l}\text { Patient intubated and } \\
\text { monitored on ventilator }\end{array}$ \\
\hline Metabolic & $\begin{array}{l}\text { Increase oxygen } \\
\text { requirements Switch from } \\
\text { aerobic to anaerobic } \\
\text { metabolism }\end{array}$ & $\begin{array}{l}\text { Energy (ATP) depletion } \\
\text { Supply/demand mismatch }\end{array}$ & $\begin{array}{l}\text { Reduced metabolic } \\
\text { requirements } \\
\text { allowing supply to meet } \\
\text { demand }\end{array}$ & $\begin{array}{l}\text { ATP reserved with reduced } \\
\text { metabolism. } \\
\text { No oxygen or substrates } \\
\text { requirements }\end{array}$ \\
\hline Coagulopathy & $\begin{array}{l}\text { Trauma-induced consumptive } \\
\text { coagulopathy } \\
\text { Reperfusion dilutional } \\
\text { coagulopathy }\end{array}$ & $\begin{array}{l}\text { Decrease platelets and } \\
\text { coagulation factors activity }\end{array}$ & $\begin{array}{l}\text { Continuous monitoring of } \\
\text { PT and PTT }\end{array}$ & Irrelevant \\
\hline Mental Status & Variable & $\begin{array}{l}\text { Progressive depression in } \\
\text { mental status and eventually } \\
\text { coma with flat EEG }\end{array}$ & $\begin{array}{l}\text { Patient deliberately sedated } \\
\text { and paralyzed }\end{array}$ & $\begin{array}{l}\text { Patient deliberately sedated } \\
\text { and paralyzed }\end{array}$ \\
\hline Immune system & $\begin{array}{l}\text { Initiation of inflammatory } \\
\text { response with multiple organ } \\
\text { damage }\end{array}$ & $\begin{array}{l}\text { Blunted cytokine production } \\
\text { and neutrophil migration with } \\
\text { increased risk of infections }\end{array}$ & $\begin{array}{l}\text { Decreased immune and } \\
\text { inflammatory response } \\
\text { Antibiotic prophylaxis }\end{array}$ & $\begin{array}{l}\text { Antibiotics coverage and } \\
\text { sepsis precaution during } \\
\text { hypothermia induction }\end{array}$ \\
\hline Shivering & $\begin{array}{l}\text { Not observed early in } \\
\text { hemorrhage }\end{array}$ & $\begin{array}{l}\text { Increased attempt to produce } \\
\text { heat increases energy demand } \\
\text { and over-utilizes ATP }\end{array}$ & $\begin{array}{l}\text { Muscular blockade to } \\
\text { control shivering. }\end{array}$ & $\begin{array}{l}\text { Muscular blockade to control } \\
\text { shivering }\end{array}$ \\
\hline Hyperglycemia & Irrelevant & $\begin{array}{l}\text { Decreased insulin production } \\
\text { and resistance leads to } \\
\text { hyperglycemia }\end{array}$ & Controlled and reversible & Controlled and reversible \\
\hline
\end{tabular}

ATP = Adenosine Tri-Phosphate. EEG = Electroencephalogram.

uate its application in the setting of hemorrhagic shock, there are numerous large and small animal studies that address this issue. These pre-clinical data suggest that the optimal protocol for bleeding trauma patients would differ depending on the severity of hemorrhage, presence or absence of additional injuries, and time required for definitive surgical repair. Thus, the published pre-clinical studies have been divided according to severity of hemorrhagic insult to correlate with different clinical scenarios.

\section{Hypotensive Bleeding Trauma Patients}

Severe bleeding is a frequent cause of hypotension and shock in trauma patients. Since hypotension does not develop until $>30-40 \%$ blood volume loss, these injuries are often fatal and must be managed rapidly to avoid death. In this patient population, our goal should be to delay the onset of cardiac arrest and create adequate time for surgical repair/control of hemorrhage, as well as provide cellular protection from ischemia/reperfusion injury during fluid resuscitation following surgery. Therapeutic hypothermia is a promising option. Mild to moderate hypothermia decreases heart rate and increases systemic vascular resistance while maintaining stroke volume and blood pressure. Hence, hypothermia decreases cardiac metabolic demands while sustaining cardiac output and myocardial perfusion [97]. In a model of uncontrolled hemorrhage, mild to moderate hypothermia induced by surface cooling delayed the onset of cardiac arrest and significantly improved survival in rats [125-127]. Large animal models confirmed that the induction of hypothermia (varying depths) after hemorrhagic shock can improve survival, and preserve organ viability and cognitive function [128-130]. These benefits were also seen in hemorrhaged animals that underwent repair of multiple concurrent injuries without an increase in postoperative complications [123]. This survival benefit can be further enhanced by coupling cooling with minimal intravenous fluid resuscitation [131].

Investigators have not only observed cardioprotective effects and survival advantage, but also systemic protection through attenuation of the inflammatory response [132]. In a small animal model of lethal hemorrhage treated with profound hypothermia, our team has demonstrated decreased lactic acidosis and improved survival along with a significant decrease in apoptotic proteins, preserved phosphorylated Akt levels, and increased prosurvival intermediates such as Bcl-2 and $\beta$-catenin proteins [101]. Similarly, in a swine model of lethal vascular injuries, profound hypothermia modulated the post- 
shock immune response by attenuating the pro-inflammatory IL-6, increasing anti-inflammatory IL-10 and augmenting the expression of protective HSP-70 protein [133]. Additional studies suggest that hypothermia can protect the brainstem from oxidative stress during hemorrhagic shock by decreasing glutathione levels [134], microvascular permeability and generation of ROS [135].

The optimal time course and depth of hypothermia in hypotensive trauma patients remains unknown. Preclinical studies indicate that mild hypothermia may be preferable to deeper cooling. This strategy would provide adequate protection while minimizing the cardiac, coagulation and immunological complications observed at lower temperatures [136]. Moreover, the ability to induce a protective hypothermic state with surface cooling makes this a suitable strategy in resource poor settings (e.g. prehospital, battlefield). With regard to duration, animal studies suggest that cooling should be initiated rapidly upon arrival and maintained during surgical repair and reperfusion, and then reversed actively once hemodynamic control has been reestablished. There is also evidence to suggest that extending mild therapeutic hypothermia beyond the early resuscitation period provides no additional benefits. In that study, rats that became spontaneously hypothermic during hemorrhagic shock demonstrated no long term survival advantage when maintained in a mildly hypothermic state for 2 or 12 hours post-resuscitation [115]. In fact, restoration of normothermia during resuscitation seems to improve cardiac and hepatic circulation and function more effectively [132].

\section{Bleeding Trauma Patient in Full Cardiac Arrest}

Hemorrhage that progresses to full arrest has dismal prognosis. Survival is unlikely unless the source of bleeding can be controlled within minutes and the damage endured during cardiovascular collapse and reperfusion minimized [137]. Emergency department thoracotomies and lengthy resuscitation efforts often fail to improve outcomes with overall survival rates of approximately 7\% $[138,139]$. Nonetheless, a notable portion of these patients die with injuries that could have been repaired, if the surgeons were afforded some additional time to do so. In this patient population, the most promising intervention in preclinical studies has been the rapid induction of profound hypothermia. This strategy, termed emergency preservation and resuscitation (EPR) is a period of drastically decreased metabolism to preserve organs and allow surgical repair, followed by controlled resuscitation. EPR aims to extend the Golden Hour and preserve organ viability using a profoundly hypothermic state, upregulate pro-survival genes and proteins, and attenuate inflammation [140-142].
Through several rigorous experiments, Dr. Peter Safar and his team at the University of Pittsburgh established the effectiveness of 'suspended animation' strategy in large animal models [143]. These studies determined that cooling to temperatures of $10-15^{\circ} \mathrm{C}$ were optimal for preservation of severely injured animals that simulated trauma patients in cardiac arrest. Following pressure-controlled hemorrhagic shock (mean arterial pressure $40 \mathrm{mmHg}$ ), induction of profound hypothermia and cardiac arrest via closed-chest cardiopulmonary bypass (CPB) for $60 \mathrm{~min}$ utes yielded $100 \%$ survival in a canine model. EPR's effectiveness following a period of shock makes it very attractive in a civilian or military setting where patients must survive significant transport times before induction of hypothermia (and surgical repair) is possible.

Profound hypothermia can also be successfully induced with high-volume saline infusion into the aorta via a femoral artery catheter [144,145]. The Pittsburgh group achieved $100 \%$ survival without significant brain damage for cardiac arrests lasting as long as 90 minutes. Other studies using controlled methods of blood exchange, (removing blood after induction of hypothermia) or after pressure controlled hemorrhage have achieved similar results [146,147]. Profound hypothermia time has been extended to 3 hours using organ-preservation fluids and low-flow CPB during cardiac arrest [148].

\section{Optimal Technique and Future Directions: Moving from Bench to Bedside}

These exciting early EPR experiments were not without limitations. All of the early EPR studies used volume and pressure controlled hemorrhage models without any associated injuries, which incompletely represents the polytrauma patients. In fact, when a mild splenic injury was added to the standard pressure controlled hemorrhagic shock (60 minutes) model, EPR's protective effects were much less impressive, with fifty percent of the animals exhibiting neurological deficits (without histological damage) [149].

Furthermore, several of the methods of hypothermic induction used in these EPR studies are not clinically realistic in trauma setting. Even though an aortic flush via femoral cut-down and the use of $\mathrm{CPB}$ are very effective methods, this requires large amounts of fluids to reach the desired degree of cooling. Obtaining femoral access in a pulseless patient presents an added challenge. Therefore, an emergent thoracotomy with direct aortic cannulation and the use of closed loop CBP with a low flow state using acellular fluids during the period of hypothermia could be more practical for rapid induction and maintenance of profound hypothermia [150]. 
To close the gap between laboratory experiments and clinical reality, our group developed new models that closely mimic the bleeding, polytrauma patients that need treatment in modern trauma medicine. These models used large animals with multiple vascular injuries causing uncontrolled hemorrhage coupled with multiple soft tissue injuries. In this way, we generated a state of "irreversible shock": a highly lethal injury that is unresponsive to traditional resuscitation with crystalloid, blood products and open cardiac massage. However, this injury can be treated successfully with EPR using profound hypothermia and controlled resuscitation on cardiopulmonary bypass [151].

We induced up to 90 minutes of profound hypothermia via an emergency thoracotomy approach to facilitate total body preservation during surgical repair and resuscitation. Long-term survival was excellent without any neurological damage or significant organ dysfunction [151]. The follow up study [127] demonstrated 75\% long-term survival could be achieved with one hour of normothermic shock simulating transport time followed by $60 \mathrm{~min}$ utes of hypothermic cardiac arrest and repair of lethal vascular injuries above and below the diaphragm. In multiple experiments using this model, all of the normothermic control animals died, whereas almost $90 \%$ of those undergoing profound hypothermia survived neurologically intact and with normal cardiac function.

Subsequent studies have outlined that maximum benefits are achieved when profound hypothermia is induced rapidly $\left(2{ }^{\circ} \mathrm{C} / \mathrm{min}\right)$ and reversed more slowly $\left(0.5^{\circ} \mathrm{C} / \mathrm{min}\right)$. Optimal depth has also been shown to be $10^{\circ} \mathrm{C}$ with decreased survival demonstrated at ultra profound temperature $\left(5^{\circ} \mathrm{C}\right)$ [152]. In our experiments, rewarming was active and begun promptly after hemorrhage was controlled using cardiopulmonary bypass with the use of blood products as needed to reverse coagulopathy and restore normal oxygen delivery. We delayed blood transfusion until after injuries were repaired and metabolic demands were increased in the re-warming period. Using this optimized model, 60 min of profound hypothermia achieved $90 \%$ survival in a model that is $100 \%$ lethal in normothermic animals.

Uniquely, coagulopathy and intraoperative bleeding are not a major problem during profound hypothermia since tissue viability is independent of oxygen delivery. Profound hypothermia renders coagulopathy and bleeding irrelevant. Shed blood could be recycled and any hypothermia-induced coagulopathies were completely reversed upon re-warming. Even in the presence of vascular, splenic, and colonic injuries, we have successfully induced profound hypothermia without a significant increase in post-operative bleeding or infection [120]. We also tested a portable, battery-operated, rotary pump to induce hypothermia in large animal model. This portable device performed as well as the conventional roller pump, and it seems to be more suitable in austere setting and prehospital environment during transport [153].

Using this optimal approach that synthesizes emergency preservation and resuscitation (EPR), we believe that irreversible severe hemorrhagic shock presenting with cardiac arrest can be successfully reversed. Contemporary EPR strategies using a flush solution supplemented with oxygen and glucose can prolong life for as long as $180 \mathrm{~min}-$ utes with adequate neurological recovery following pressure controlled hemorrhage [154]. Many questions remain and improved life-preserving strategies desired. What is the maximum duration for EPR in the care of bleeding, polytrauma patients? Since hypothermia does not completely abolish metabolic activity, could EPR be augmented by alternative resuscitation fluids or cell preserving therapies [155]?

\section{Conclusions}

From our extensive pre-clinical experience and review of the current literature, we contend that induced hypothermia can protect tissues and improve survival in bleeding polytrauma patients. Moreover, EPR strategies can effectively prolong survivable ischemia time in pulseless trauma patients and buy additional time for surgical repair of exsanguinating injuries followed by early fluid resuscitation. Significant advances have been made in our understanding of the physiological, inflammatory, and cell biological changes that facilitate the protective effects of therapeutic hypothermia and the deleterious consequences of spontaneous hypothermia. Thus, although it is important to acknowledge that hypothermia is a double edge sword, our ability to make significant strives in clinically-relevant experiments should encourage us to bridge the gap between bench and bedside. As the mortality rate from hemorrhagic shock continues to rise, it is incontrovertible that further research, in the form of a rigorous, controlled clinical trial, must be done to translate these promising findings into trauma practice.

\section{Competing interests}

The authors declare that they have no competing interests.

\section{Authors' contributions}

HA conceived the project and provided the overall structure of the manuscript. TK and AK performed the literature review and composed the manuscript. All of authors read and approved the final manuscript.

\section{Acknowledgements}

Hypothermia research performed by Dr. Alam was supported by a research grant from the National Institutes of Health. 


\section{References}

I. Burch JM, Ortiz VB, Richardson RJ, Martin RR, Mattox KL, Jordan GL Jr: Abbreviated laparotomy and planned reoperation for critically injured patients. Ann Surg 1992, 2 I 5:476-483.

2. Stefanutti G, Pierro A, Parkinson EJ, Smith VV, Eaton S: Moderate hypothermia as a rescue therapy against intestinal ischemia and reperfusion injury in the rat. Crit Care Med 2008, 36: $1564-1572$.

3. Ehrlich MP, McCullough JN, Zhang N, Weisz DJ, Juvonen T, Codian CA, Greipp RB: Effect of hypothermia on cerebral blood flow and metabolism in the pig. Ann Thorac Surg 2002, 73:191-197.

4. Heron MP, Hoyert DL, Xu J, Scott C, Tejada-Vera B: Deaths: Preliminary data for 2006. National Vital Statistics Report 2008, 56( I 6): 1-52.

5. Salmela R: Mortality trends and health policy in the Scandinavian countries: Surveillance of mortality in the Scandinavian countries 1947 - 1993. Health Policy 1996, 38(2): I29-I3I.

6. Corso P, Finkelstein E, Miller T, Fiebelkorn I, Zaloshnja E: Incidence and lifetime costs of injuries in the United States. Injury Prevention 2006, I2:212-218.

7. Alam HB, Rhee P: New development in fluid resuscitation. Surg Clin Notrth Sm 2007, 87( I ):55-72.

8. Bickell WH, Wall MJ Jr, Pepe PE, Martin RR, Ginger VF, Allen MK, Mattox KL: Immediate versus delayed fluid resuscitation for hypotensive patients with penetrating torso injuries. N Eng J Med 1994, 33 I(I 7): I I05-I I09.

9. Pope A, French G, Longnecker DE: Fluid Resuscitation: State of the Science for Treating Combat Casualties and Civilian Injuries. Washington DC, Institute of Medicine, National Academy Press; 1999.

10. Holcomb JB: Methods for improved hemorrhage control. Crit Care 2004, 8(Suppl 2):S57-S60

II. Sauaia A, Moore FA, Moser KS, Brennan R, Read RA, Pons PT: Epidemiology of trauma deaths: a reassessment. J trauma 1995, 38(2): 185-193.

12. Heckbert SR, Vedder NB, Hoffman W, Winn RK, Hudson LD, Jurkovich GJ, Copass MK, Harlan JM, Rice CL, Maier RV: Outcome after hemorrhagic shock in trauma. I Trauma 1998, 45(3):545-549.

13. Cole SL, Corday E: Four-minute limit for cardiac resuscitation. JAMA 1956, I 6 I (1 5): | 454- | 458.

14. Jennings RB, Reimer KA, Steenbergen CP: Complete global myocardial ischemia in dogs. Crit Care Med 1988, I 6( I 0):988-996.

15. Radovsky A, Safar P, Sterz F, Leonov Y, Reich H, Kuboyama K: Regional Prevalence and Distribution of Ischemic Neurons in Dog Brains 96 Hours After Cardiac Arrest of 0 to 20 Minutes. Stroke 1995, 26(I I):2127-2I33.

16. American College of Surgeons: ATLS, Advanced TraumaLife Support Program for Doctors. Amer College of Surgeons; 2008.

17. Barcoft J: Presidential address on anoxaemia. The Lancet 1920 I 96(5062):485-489.

18. Ukikusa M, Kamiyama Y, Sato T, Tanaka J, Jones RT, Cowlev RA, Trump BF: Pathophysiology of hemorrhagic shock II. Anoxic metabolism of the rat liver following acute blood loss in the rat. Circ Shock 1981, 8(4):483-490.

19. Shoemaker W: Oxygen transport and oxygen metabolism in shock and critical illness. Invasive and noninvasive monitoring of circulatory dysfunction and shock. Crit Care Clin 1996, I 2(4):939-969.

20. Chaudry $\mathrm{IH}$ : Cellular mechanisms in shock and ischemia and their correction. Am J Physiol I983, I4:R II7-R I34.

21. Keller ME, Aihara R, LaMorte WW, Hirsh EF: Organ-specific changes in high energy phosphates after hemorrhagic shock and resuscitation in the rat. I Am Coll Surg 2003, I 69(5):685-690.

22. Chaudry IH, Sayeed MM, Baue AE: Effect of hemorrhagic shock on tissue adenine nucleotide in conscious rats. Can J Physiol Pharmacol | 974, 52:131-137.

23. Chaudry IH, Sayeed MM, Baue AE: Alterations in high-energy phosphates in hemorrhagic shock as related to tissue and organ function. Surgery 1976, 79:666-668.

24. Hochachka PW, Buck LT, Doll CJ, Land SC: Unifying theory of hypoxia tolerance: molecular metabolic defense and rescue mechanisms for surviving oxygen lack. Proc Natl Acad Sci USA 1996, 93( I 8):9493-9498.

25. Guillemin K: The hypoxic response: Huffing and HIFing. Cell 1997, 89:9-12
26. Dougherty CJ, Kubasiak LA, Frazier DP, Li H, Xiong WC, Bishopric $\mathrm{NH}$, Webster KA: Mitochondrial signals initiate the activation of c-Jun N-Terminal kinase (JNK) by hypoxia-reoxygenation. FASEB J 2004, I 8( I 0): 1060-1070.

27. Palmer LA, Semenza GL, Stoler MH, Johns RA: Hypoxia induces type II NOS gene expression in pulmonary artery endothelial cells via HIF-I. Am J Physiol Lung Cell Mol Physiol I998, 274(2): L2 I 2-L219.

28. Hierholzer C, Harbrecht B, Menezes JM, Kane J, MacMicking J, Nathan CF, Peltzman AB, Billiar TR, Tweardy DJ: Essential role of induced nitric oxide in the initiation of the inflammatory response after hemorrhagic shock. J Exp Med 1998, I87(6):917-928.

29. Fink MP: Cytopathic hypoxia: Mitochondrial dysfunction as mechanism contributing to organ dysfunction in sepsis. Crit Care Clin 200I, I 7( I):219-237.

30. Baue AE, Sayeed MM, Wueth MA: Potential relationships of changes in cell transport and metabolism in shock. Adv Exp Med Biol 1972, 33(0):253-62.

31. Greenwald JW, Rossi CS, Lehninger AL: Effect of active accumulation of calcium and phosphate ions on the structure and function of rat liver mitochondria. J Cell Bio I964, 23(I):21-38.

32. Husain FA, Martin MJ, Mullenix PS, Steele SR, Elliott DC: Serum lactate and base deficit as predictors of mortality and morbidity. Am J Surg 2003, I 85(5):485-49I.

33. Carroll RG, lams SG, Pryor WH Jr, Allison EJ Jr: Prevention of "irreversible" hemorrhagic shock by preservation of cellular integrity. Med Hypotheses 1987, 24(I):69-75.

34. Ohkawa M, Chaudry IH, Clemens MG, Baue AE: ATP-MgCl2 produces sustained improvement in hepatic mitochondrial function and blood flow after hepatic ischemia. J Surg Res 1984, 37(3):226-234.

35. Chaudry IH, Ohkawa M, Clemens MG: Improved metochondrial function following ischemia and reflow by ATP-MgCI2. Am J Physiol 1984, 246(5 pt2):R799-804.

36. Wang $\mathrm{P}, \mathrm{Ba}$ ZF, Dean RE, Chaudry IH: ATP-MgCl2 restores depressed hepatocellular function and hepatic blood flow following hemorrhage and resuscitation. I Surg Res 1991, 50(4):368-374.

37. Wang $P$, Zhou M, Rana MW, Singh G, Ba ZE, Ayala A, Chaudry IH: ATP-MgCl2 restores renal microcirculation following trauma and severe hemorrhage. Can J Physiol Pharmacol 1992, 70(3):349-357.

38. Wang $\mathrm{P}, \mathrm{Ba} \mathrm{ZE}$, Chaudry IH: ATP-MgCl2 restores depressed cardiac output following trauma and severe hemorrhage even in the absence of blood resuscitation. Circ Shock 1992 , 36(4):227-283.

39. Chaudry IH: ATP-MgCl2 and liver blood flow following shock and ischemia. Prog Clin Biol Res 1989, 299:|9-3।.

40. Chaudry IH, Sayeed MM, Baue AE: Effect of adenosine triphosphate-magnesium chloride administration in shock. Surgery 1974, 75:220-227.

4I. Machiedo GW, Ghuman S, Rush BF Jr, Kraven T, Dikdan G: The effect of ATP-MgCl2 infusion on hepatic cell permeability and metabolism after hemorrhagic shock. Surgery 198I, 90(2):328-335.

42. DiStazio J, Maley W, Thompson B, Sembrat R, Stremple J: Effect of ATP-MgCl2-glucose administration during hemorrhagic shock on cardiovascular function, metabolism, and survival. Adv Shock Res 1980, 3:153-166.

43. Cotton BA, Guy JS, Morris JA Jr, Abumrad NN: The cellular, metabolic, and systemic consequences of aggressive fluid resuscitation strategies. Shock 2006, 26:115-121.

44. Mollen KP, McCloskey CA, Tanaka H, Prince JM, Levy RM, Zuckerbraun BS, Billiar TR: Hypoxia activates c-jun $\mathbf{N}$-terminal kinase via RACI-dependent reactive oxygen species production in hepatocytes. Shock 2007, 28(3):270-277.

45. Li C, Jackson RM: Reactive species mechanisms of cellular hypoxia-reoxygenation injury. Am J Physiol Cell Physiol 2002, 282:C227-C24I.

46. Tamion F, Richard V, Bonmarchand G, Leroy J, Hiron M, Daveau M, Thuillez C, Leberton JP: Reduced synthesis of inflammatory cytokines by a free radical scavenger after hemorrhagic shock in rats. Crit Care Med 2000, 28:2522-2527.

47. Heirholzer C, Kelly E, Billiar TR, Tweardy DJ: Granulocyte colonystimulating factor (G-CSF) production in hemorrhagic shock 
requires both ischemic and resuscitation phase. Arc Orthop Trauma Surg 1997, I 16(3): 173-176.

48. Meldrum DR, Shenker R, Sheridan BC, Cain BS, Abraham E, Harken $\mathrm{AH}$ : Hemorrhage activates myocardial NFkappaB and increases TNF-alpha in the heart. J Mol Cell Cardiol 1997, 29(10):2849-2854.

49. Hierholzer C, Kalff JC, Billir TR, Tweardy DJ: Activation of STAT proteins in the lung of rats following resuscitation from hemorrhagic shock. Arch Orthop Trauma Surg 1998, I I 7(6-7):372-375.

50. Harvath CM: STAT proteins and transcriptional responses to extracellular signals. Trends Biochem Sci 2000, 25(10):496-502.

5I. Hierholzer C, Kalff JC, Omert L, Tsukada K, Leoffert JE, Watkins SC, Billiar TR, Teardy DJ: Interleukin-6 production in hemorrhagic shock is accompanied by neutrophile recruitment and lung injury. Am J Physiol Lung Cell Mol Physiol I998, 275:6 I I-62 I.

52. Klebanoff SJ, Vadas MA, Harlan VJ, Sparks LH, Gamble JR, Agosti JM, Waltersdroph AM: Stimulation of neutrophils by tumor necrosis factor. J Immuno 1986, I 36(I I):4220-4225.

53. Jernigan TW, Croce MA, Fabian TC: Apoptosis and necrosis in the development of acute lung injury after hemorrhagic shock. Am Surg 2004, 70(I 2): 1094-1098.

54. Barlos D, Deitch EA, Watkins AC, Caputo FJ, Lu Q, Abungu B, Colorado I, Xu D, Feinman R: Trauma-hemorrhagic shock-induced pulmonary epithelia and endothelial cell injury utilizes different programmed cell death signaling pathways. Am J Physiol Lung Cell Mol Physiol 2009, 296:404-4I7.

55. Guan J, Jin D, Jin L, Lu Q: Apoptosis in organs of rats in early stage after polytrauma combined with shock. J Trauma 2002, 52:104-111.

56. Yu ZY, Ono S, Spatz M, McCarron RM: Effect of hemorrhagic shock on apoptosis and energy-dependent efflux system in the brain. Neruochem Res 2002, 27(I 2):1625-1632.

57. Hostmann A, Jasse K, Schulze-Tanzil G, Robinson Y, Oberholzer A Ertel W, Tschoeke SK: Biphasic onset of splenic apoptosis following hemorrhagic shock: critical implications for Bax, Bcl2, and Mcl-I proteins. Crit Care 2008, I 2(I):R8.

58. Bhatia M, Moochhala S: Role of inflammatory mediators in the pathophysiology of acute respiratory distress syndrome. J Pathol 2004, 202(2): 145-56.

59. Swan H: Clinical hypothermia: a lady with a past and some promises for the future. Surgery 1973, 73(5):736-758.

60. Henderson AR, Fay T: Unconformable Crusader and Harbinger of Human Refrigeration. J Neurosurg 1963, 20:627-34.

6I. Talbot JH: Physiologic and therapeutic effects of hypothermia. N Engl] Med [94I, 224:28I-288.

62. Vandam LD, Burnap KB: Hypothermia. N Engl J Med 1959, 26 I:546-553.

63. Helling PM: Controlled Hypothermia. $\mathrm{Br}$ Med J 1958 , 2(5092):346-350.

64. Huguernard P: Hibernation artificielle. Rev Prat 1952, 2:1725-1729.

65. Ferguson AT, Wilson JN, Jenkins D, Swan H: The effect of hypothermia on hemorrhagic shock. Ann Surg 1958, I47(3):28I-288.

66. Jonas RA: Deep hypothermic circulatory arrest: current status and indications. Semin Thorac Cardiovasc Surg Pediatr Card Surg Annu 2002, 5:76-88.

67. Rothoerl RD, Brawanski A: The history and present status of deep hypothermia and circulatory arrest in cerebrovascular surgery. Neurosurg focus 2006, 20(6): E5.

68. Post Cardiac Arrest Early Goal Directed Therapy. Center for Resuscitation Science. 2006. University of Pennsylvania School of Medicine [http://www.med.upenn.edu/resuscitation/hypothermia/images/ HypothermiaDiagrams]

69. Bernard S, Buist M, Monteiro O, Smith K: Induced hypothermia using large volume, ice-cold intravenous fluid in comatose survivors of out-of-hospital cardiac arrest: a preliminary report. Resuscitation 2003, 56(I):9-13.

70. Alam HB: To cool or not to cool, that is the question. Crit Care Med 2007, 35(2):660-662.

7I. Safar PJ, Tisherman SA: Suspended animation for delayed resuscitation. Curr Opin Anaesthesiol 2002, 15(2):203-210.

72. Wu X, Kochanek PM, Cochran K, Nozari A, Henchir J, Stezoski SW Wagner R, Wisniewski S, Tisherman SA: Mild hypothermia improves survival after prolonged traumatic hemorrhagic shock in pigs. I Trauma 2005, 59(2):291-299.
73. Takasu A, Norio H, Gotoh Y, Sakamoto T, Okadaa Y: Efect of induced hypothermia on short-term survival after volumecontrolled hemorrhage in pigs. Resuscitation 2003, 56(3):319-328.

74. Alam HB, Bowyer MW, Koustova E, Gushchin V, Anderson D, Stanton K, Kreishman P, Cryer CM, Hancock T, Rhee P: Learning and memory is preserved after induced asanguineous hyperkalemic hypothermic arrest in a swine model of traumatic exsanguination. Surgery 2002, 132(2):278-288.

75. Wang HE, Callaway CW, Peitzman AB, Tisherman SA: Admission hypothermia and outcome after major trauma. Crit Care Med 2005, 33:|296-30|.

76. Tisherman SA: Suspended animation for resuscitation from exsanguinating hemorrhage. Crit Care Med 2004, 32:46-50.

77. Luna GK, Maier RV, Pavlin EG, Anardi D, Copass MK, Oreskovich MR: Incidence and effect of hypothermia in seriously injured patients. J trauma 1987, 27(9): $1014-1018$

78. Shafi S, Elliot AC, Gentilello L: Is hypothermia simply a marker of shock and injury severity or an independent risk factor for mortality in trauma patients? Analysis of a large national trauma registry. J Trauma 2005, 59: I08I- 1085.

79. Gregory JS, Flancbaum L, Townsend MC, Coultier CT, Jonasson O: Incidence and timing of hypothermia in trauma patients undergoing operations. J Trauma |99|, 3 I (6):795-800.

80. Jurkovich G], Greiser WB, Luterman A, Curreri PW: Hypothermia in trauma victims: an ominous predictor of survival. I trauma 1987, 27(9): 1019-1024.

8I. Gentilello LM, Jurkovich G], Stark MS, Hassantash SA, O'Keefe GO: Is hypothermia in the victim of major trauma protective or harmful? Ann Surgery 1997, 226(4):439-449.

82. de Meis L, Bianconi ML, Suzano VA: Control of energy fluxes by the sarcoplasmic reticulum Ca-ATPase: ATP hydrolysis, ATP synthesis and heat production. FESB letters 1997 , 406:20I-204.

83. Seekamp A, van Griensven M, Hildebrandt F, Wahlers T, Tscherne H: Adenosis-triphosphate in trauma-related and elective hypothermia. J Trauma 1999, 47(4):673-683.

84. Wong KC: Physiology and pharmacology of hypothermia. West J med 1983, I 38(2):227-232.

85. Haman F: Shivering in the cold: from mechanisms of fuel selection to survival. J Appl Physiol 2006, 100: 1702-1708.

86. Prakash O, Jonson B, Bos E, Meji S, Hugenholtz PG, Hekman W: Cardiorespiratory and metaboilc effects of profoundhypothermia. Crit Care Med 1978, 6(5):340-346. abstract

87. Mizushuma Y, Wang O, Cioffi WG, Bland KI, Chaudry IH: Should normothermia be restored and maintained during resuscitation after trauma and hemorrhage. J Trauma 2000, 48(I):58-65.

88. Reuler JBL: Hypothermia: Pathophysiology, clinical settings and management. Ann Intern Med 1978, 89:5 19-527.

89. Hildebrand F, Giannoudis PV, van Griensven M, Chawda M, Pape HC: Pathophysiologic changes and effects of hypothermia on outcome in elective surgery and trauma patients. Am J Surg 2004, I87:363-37I.

90. Krause KR, Howells GA, Buhs CL, Hernandez DA, Bair H, Schuster $M$, Bendick P]: Hypothermia-induced coagulopathy during hemorrhagic shock. Am Surg 2000, 66(4):348-354.

91. Bellamy R, Safar P, Tisherman SA, Basford R, Bruttig SP, Capone A, Dubick MA, Ernster L, Hattler BG Jr, Hochachka P, Klain M, Kochanek PM, Kofke WA, Lancaster JR, McGowan FX Jr, Oeltgen PR, Severinghaus JW, Taylor MJ, Zar H: Suspended animation for delayed resuscitation. Crit Care Med 1996, 24((2S)(Supplement)):24S-47S.

92. Alzaga AG, Cerdan M, Varon J: Therapeutic hypothermia. Resuscitation 2006, 70(3):369-380.

93. Storey KB, Storey JM: Tribute to P.L Lutz: Putting life on 'pause' - molecular regulation of hypometabolism. J Exp Biol 2007, 210:1700-17|4.

94. Marubayashi S, Takenaka M, Dohi K, Ezaki H, Kawasaki T: Adenine nucleotide metabolism during hepatic ischemia and subsequent blood flow periods and its relation to organ viability. Transplantation 1980, 30(4):294-296.

95. Tsukamoto K, Murakami M, Seo Y, Nonaka M, Kohnosu H, Hironaka $\mathrm{T}$, Oka T, Watari $\mathrm{H}$ : Energetic recovery from hypothermic preservation in the rat liver. J Surg Res 1990, 48(I):46-50. 
96. Eidelman Y, Glat PM, Pachter HL, Cabrera R, Rosenberg C: The effects of topical hypothermia and steroids on AP levels in an in vivo liver ischemia model. J Trauma 1994, 37(4):677-68।.

97. Meyer DM, Horton JW: Effect of moderate hypothermia in the treatment of canine hemorrhagic shock. Ann Surg 1988, 207(4):462-469.

98. Ibayashi S, Takano K, Ooboshi H, Kitazono T, Sadoshima S, Fujishima $\mathrm{M}$ : Effect of selective brain hypothermia on regional cerebral blood flow and tissue metabolism using brain thermo-regulator in spontaneously hypertensive rats. Neurochem Res 2000, 25(3):369-375.

99. Erecinska M, Thoresen M, Silver IA: Effects on hypothemria on energy metabolism in mammalian central nervous system. J Cereb Blood Flow Metab 2003, 23(5):5 I 3-530.

100. Ning XH, Chen SH, Xu CS, Li L, Yao LY, Qian K, Krueger J], Hyyti OM, Portman MA: Selected contribution: Hypothermic protection of ischemic heart via alterations in apoptotic pathways as assessed by gene array analysis. J Appl Physiol 2002, 92:2200-2207.

10I. Shuja F, Tabbara M, Li Y, Baoling Liu, Butt MU, Velmahos GC, deMoya M, Alam HB: Profound Hypothermia Decreases Cardiac Apoptosis Through Akt Survival Pathway. Journal of the American College of Surgeons 2009, 209(I):9-99.

102. Lotocki G, de Rivero Vaccari JP, Perez ER, Alonso OF, Curbelo K, Keane RW, Dietrich WD: Therapeutic hypothermia modulates TNFRI signaling in the traumatized brain via early transient activation of JNK pathway and suppression of XIAP cleavage. Eur J Neurosci 2006, 24(8):2283-2290.

103. Fu T, Blei AT, Takamura N, Lin T, Guo D, Li H, O'Gorman MR, Soriano HE: Hypothermia inhibits Fas-mediated apoptosis of primary mouse hepatocytes in culture. Cell Transplant 2004, 13(6):667-676.

104. Parkinson EJ, Townsend PA, Stephanou A, Latchman DS, Eaton S, Pierro A: The protective effect of moderate hypothermia during intestinal ischemia-reperfusion is associated with modification of hepatic transcription factor activation. J Pediatr Surg 2004, 39(5):696-70I.

105. Patel S, Pachter HL, Yee H, Schwartz JD, Marcus SG, Shamamian P: topical hepatic hypothermia attenuates pulmonary injury after hepatic ischemia and reperfusion. J Am Coll Surg 2000 I 9 I(6):650-656

106. Huet O, Kinirons B, Dupic L, Lajeunie E, Mazoit JX, Benhamou D, Vicaut $E$, Duranteau J: Induced mild hypothermia reduces mortality during acute inflammation in rats. J Acta Anaesthesio Scand 2007, 5 I (9): 12||$-6$

107. Qing M, Vazquez-Jimenez JF, Klosterhalfen B, Sigler M, Schumacher K, Duchateau J, Messmer B], von Bernuth G, Seghaye MC: Influence of temperature during cardiopulmonary bypass on leukocyte activation, cytokine balance, and post-operative organ damage. Shock 200I, 15(5):372-7.

108. Menasché P, Haydar S, Peynet J, Du Buit C, Merval R, Bloch G, Piwnica $A$, Tedgui A: A potential mechanism of vasodilation after warmheart surgery. The temperature-dependent release of cytokines. J Thorac Cardiovasc Surg 1994, 107(1):293-9.

109. Fairchild KD, Viscardi RM, Hester L, Singh I, Hasday JD: Effects of hypothermia and hyperthermia on cytokine production by cultured human mononuclear phagocytes from adults and newborns. J Interferon Cytokine Res 2000, 20:1049-1055.

I I0. Lee SL, Felix DB, Kyoto G: Hypothermia induces T-cell production of immunosuppressive cytokines. J Surg Res 200I, 100(2): $150-153$.

III. Kempainen RR, Brunette DD: The evaluation and management of accidental hypothermia. Respir Care 2004, 49(2): 192-205.

I 12. Peterson K, Carson S, Carney N: Hypothermia treatment for traumatic brain injury: a systematic review and meta-analysis. J Neurotrauma 2008, 25(I):62-7I.

1 13. Adelson PD, Ragheb J, Kanev P, Brockmeyer D, Beers SR, Brown SD, Cassidy LD, Chang Y, Levin H: Phase II clinical trial of moderate hypothermia after severe traumatic brain injury in children. Neurosurgery 2005, 56(4):740-754.

114. Valeri CR, Feingold H, Cassidy G, Ragno G, Khuri S, Altschule MD: Hypothermia-induced reversible platelet dysfunction. Ann Surg 1987, 205(2): 175-|8|.

1 15. Wu X, Stezoski J, Safar P, Nozari A, Tisherman SA: After spontaneous hypothermia during hemorrhagic shock, continuing mild hypothermia (34 degree $\mathbf{C}$ ) improves early but not late survival in rats. J Trauma 2003, 55(2):308-16.

116. Mossad EB, Machado S, Apostolakis J: Bleeding following deep hypothermia and circulatory arrest in children. Semin Cardiothorac Vasc Anesth 2007, I I ( I):34-46.

1 17. Patt A, McCroskey BL, Moore EE: Hypothermia-induced coagulopathies in trauma. Surg Clin North Am 1988, 68(4):775-785.

118. Harris OA, Colford JM Jr, Good MC, Matz PG: The role of hypothermia in the management of severe brain injury: a metaanalysis. Arch Neurol 2002, 59(7): 1077-83.

119. Kruz A, Sessler DI, Lenhardt R: Perioperative normothermia to reduce the incidence of surgical-wound infection and shorten hospitalization. Study of Wound Infection and Temperature Group. N Eng J Med 1996, 334(19): 1209-12 I5.

120. Alderson P, Signorini D, Patil C: Therapeutic hypothermia for head injury. Cochrane Database of Systematic Reviews 2008:4.

121. Bernard SA, Gray TW, Buist MD, Jones BM, Silvester W, Gutteridge G, Smith K: Treatment of comatose survivors of out-of-hospital cardiac arrest with induced hypothermia. N Engl J Med 2002, 346(8):557-563.

122. Arrich J, European Resuscitation Council Hypothermia After Cardiac Arrest Registry Study Group: Clinical application of mild therapeutic hypothermia after cardiac arrest. Crit Care Med 2007, 35(4): $104 \mid-1047$

123. Sailhamer EA, Chen Z, Ahuja N, Velmahos G, DeMoya M, Shults C, Alam HB: Profound hypothermic cardiopulmonary bypass facilitates survival without high complication rate in swine model of complex vascular, splenic, and colon injuries. J $A M$ Coll Surg 2007, 204(4):643-652.

124. Tortorici MA, Kochanek PM, Poloyac SM: Effects of hypothermia on drug disposition, metabolism, and response: $A$ focus of hypothermia-mediated alterations on the cytochrome P450 enzyme system. Crit Care Med 2007, 35(9):2196-2204.

125. Kim S, Stezoski WS, Safar P, Tisherman S: Hypothermia, but not $100 \%$ oxygen breathing, prolongs survival times during lethal uncontrolled hemorrhagic shock in rats. J Trauma 1998 44:485-490.

126. Lee KR, Chung SP, Park IC, Kim SH: Effect of induced and spontaneous hypothermia on survival time in uncontrolled hemorrhagic shock rat model. Yonsei Med J 2002, 43:5 II-5I7.

127. Takasu A, Norio H, Sakamoto T, Okada Y: Mild hypothermia prolongs the survival time during uncontrolled hemorrhagic shock in rats. Resuscitation 2002, 54:303-309.

128. Wu X, Kochanek PM, Cochran K, Nozari A, Henchir J, Stezoski SW, Wagner R, Wisniewski S, Tisherman SA: Mild hypothermia improves survival after prolonged traumatic hemorrhagic shock in pigs. J Trauma 2005, 59(2):291-299.

129. Takasu A, Norio H, Gotoh Y, Sakamoto T, Okadaa Y: Efect of induced hypothermia on short-term survival after volumecontrolled hemorrhage in pigs. Resuscitation 2003 , 56(3):319-328

130. Alam HB, Bowyer MW, Koustova E, Gushchin V, Anderson D, Stanton K, Kreishman P, Cryer CM, Hancock T, Rhee P: Learning and memory is preserved after induced asanguineous hyperkalemic hypothermic arrest in a swine model of traumatic exsanguination. Surgery 2002, 132(2):278-288.

13I. Kim S, Stezoski WS, Safar P, Capone A, Tisherman SA: Hypothermia and minimal fluid resuscitation increases survival after uncontrolled hemorrhagic shock in rats. I Trauma 1997, 42:213-22.

132. Mizushima Y, Wang P, Cioffi WG, Bland KI, Chaudry IH: Should normothermia be restored and maintained during resuscitation after trauma and hemorrhage. J Trauma 2000, 48:58-65.

133. Chen Z, Chen H, Rhee P, Koustova E, Ayuste EC, Honma K, Nadel A, Alam HB: Induction of profound hypothermia modulates the immune/inflammatory response in a swine model of lethal hemorrhage. Resuscitation 2005, 66(2):209-216.

134. Guven H, Amanvermez R, Malazgirt Z, Kaya E, Doganay Z, Celik C, Ozkan K: Moderate hypothermia prevents brain stem oxidative stress injury after hemorrhagic shock. I Trauma 2002, 53(I):66-72.

135. Childs EW, Udobi KF, Hunter FA: Hypothermia reduces microvascular permeability and reactive oxygen species expression after hemorrhagic shock. J Trauma 2005, 58(2):27I-277.

136. Danzl DF, Pozos RS: Accidental hypothermia. N Engl ] Med I994, 33I: 1756-60. 
137. Sumann G, Kampfl A, Wenzel V, Schobersberger W: Early intensive care unit intervention for trauma care: what alters the outcome? Curr Opin Crit Care 2002, 8(6):587-592.

138. Rhee PM, Acosta J, Bridgeman A, Wang D, Jordan M, Rich N: Survival after emergency department thoracotomy: review of published data from the past $\mathbf{2 5}$ years. J Am Coll Surg 2000, 190(3):288-298.

139. Brown SE, Gomez GA, Jacobson LE, Scherer T, McMillan RA: Penetrating chest trauma: should indications for emergency room thoracotomy be limited? Am Surg 1996, 62(7):530-533.

140. Kimura A, Sakurada S, Ohkuni H, Todome Y, Kurata K: Moderate hypothermia delays proinflammatory cytokine production of human peripheral blood mononuclear cells. Crit Care Med 2002, 30(7): I 499-1502.

14I. Ning XH, Chen SH, Xu CS, Li L, Yao LY, Qian K, Krueger J], Hyyti OM, Portman MA: Hypothermic protection of the ischemic heart via alterations in apoptotic pathways as assessed by gene array analysis. J Appl Physiol 2002, 92(5):2200-2207.

142. Hassoun HT, Kozar RA, Kone BC, Safi HJ, Moore FA: Intraischemic hypothermia differentially modulates oxidative stress proteins during mesenteric ischemia/reperfusion. Surgery 2002, 132(2):369-376.

143. Tisherman SA, Safar P, Radovsky A, Peitzman A, Sterz F, Kuboyama $K$ : Therapeutic deep hypothermic circulatory arrest in dogs: a resuscitation modality for hemorrhagic shock with "irreparable injury.". I Trauma 1990, 30:836-847.

144. Woods RJ, Prueckner S, Safar P, Radovsky A, Takasu A, Stezoski SW, Stezoski J, Tisherman SA: Hypothermic aortic arch flush for preservation during exsanguination cardiac arrest of 15 minutes in dogs. J Trauma 1999, 47(6): 1028-1036.

145. Behringer W, Safar P, Wu X, Kentner R, Radovsky A, Kochanek PM, Dixon CE, Tisherman SA: Survival without brain damage after clinical death of 60-120 mins in dogs using suspended animation by profound hypothermia. Crit Care Med 2003, 3 I(5): $|523-| 53 \mid$.

146. Bailes JE, Leavitt ML, Teeple E Jr, Maroon JC, Shih SR, Marquardt M, Rifai $A E$, Manack L: Ultraprofound hypothermia with complete blood substitution in a canine model. J Neurosurg |99|, 74(5):78I-788.

147. Klebanoff G, Phillips J: Temporary suspension of animation using total body perfusion and hypothermia: a preliminary report. Cryobiology 1969, 6(2): |21-125.

148. Taylor MJ, Bailes JE, Elrifai AM, Shih SR, Teeple E, Leavitt ML, Baust JG, Maroon JC: A new solution for life without blood. Asanguineous low-flow perfusion of a whole-body perfusate during 3 hours of cardiac arrest and profound hypothermia. Circulation 1995, 9 I(2):431-444.

149. Nozari A, Safar P, Wu X, Stezoski WS, Henchir J, Kochanek P, Klain $M$, Radovsky A, Tisherman SA: Suspended animation can allow survival without brain damage after traumatic exsanguination cardiac arrest of $\mathbf{6 0}$ minutes in dogs. J Trauma 2004 57(6): $1266-1275$.

150. Rhee P, Talon E, Eifert S, Anderson D, Stanton K, Koustova E, Ling G, Burris D, Kaufmann C, Mongan P, Rich NM, Taylor M, Sun L: Induced hypothermia during emergency department thoracotomy: an animalmodel. J Trauma 2000, 48(3):439-47. discussion 447-50

15I. Alam HB, Duggan M, Li Y, Spaniolas K, Liu B, Tabbara M, Demoya M, Sailhamer EA, Shults C, Velmahos GC: Putting life on hold-for how long? Profound hypothermic cardiopulmonary bypass in a Swine model of complex vascular injuries. J Trauma 2008, 64(4):912-922.

152. Alam HB, Chen Z, Li Y, Velmahos G, DeMoya M, Keller CE, Toruno $\mathrm{K}$, Mehrani T, Rhee $\mathrm{P}$, Spaniolas K: Profound hypothermia is superior to ultraprofound hypothermia in improving survival in a swine model of lethal injuries. Surgery 2006, I 40(2):307-3|4.

153. Alam HB, Casas F, Chen Z, Smith WA, Reeves A, Velmahos G, de Moya M, Rhee P: Development and testing of portable pump for the induction of profound hypothermia in a Swine model of lethal vascular injuries. I Trauma 2006, 6I(6): I32I-9.

154. Wu X, Drabek T, Tisherman SA, Henchir J, Stezoski SW, Culver S, Stezoski J, Jackson EK, Garman R, Kochanek PM: Emergency preservation and resuscitation with profound hypothermia, oxygen, and glucose allows reliable neurological recovery after $3 \mathbf{h}$ of cardiac arrest from rapid exsanguination in dogs. Cereb Blood Flow Metab 2008, 28(2):302-I I.
155. Aslami H, Schultz MJ, Juffermans NP: Potential applications of hydrogen sulfide-induced suspended animation. Curr Med Chem 2009, I6(I0): 1295-303.

Publish with Biomed Central and every scientist can read your work free of charge

"BioMed Central will be the most significant development for disseminating the results of biomedical research in our lifetime. "

Sir Paul Nurse, Cancer Research UK

Your research papers will be:

- available free of charge to the entire biomedical community

- peer reviewed and published immediately upon acceptance

- cited in PubMed and archived on PubMed Central

- yours - you keep the copyright
BioMedcentral 